\title{
Palynostratigraphic and Paleoenvironmental Study of an Offshore Well in the Niger Delta Nigeria
}

\section{Dairo VA* and Oyewole EO \\ Department of Physical and Earth Sciences, Crawford University, Nigeria}

*Corresponding author: Dairo Victoria Abiola, Department of Physical and Earth

\section{Research Article}

Volume 2 Issue 1

Received Date: April 17, 2019

Published Date: May 14, 2019 Sciences, Crawford University, Nigeria, Tel: +234 806242 5933; Email: biola02ng@yahoo.com

\section{Abstract}

Palynomorphs were employed in this study to deduce the palynozones, age and paleoenvironment of an exploratory well drilled in the Niger Delta area.

Sixty (60) ditch cutting samples were selected at intervals of $60 \mathrm{ft}$ from the depth of $6110 \mathrm{ft}$ to $11690 \mathrm{ft}$ and subjected to palynological laboratory analysis. The residual samples which comprise of Particulate Organic Matter (POM) were identified under optical microscope and the information from the abundance of pollens and spores identified were imputed into the Stratabug software.

The lithostratigraphy of the section penetrated by the well comprises of intercalation of sandy mudstone, argillaceous sandstone to coarse sandstone. Also, a total of one hundred (100) palynomorph species were identified, out of which some marker species such as Botryococcus braunii, Laevigatosporites sp, Striatopollis catatumbus, Stiamoncolpites rectostriatus, Peregrinipollis nigericus, Cicatricosisporites dorogensis, Verrucatosporites sp, and Pachydermites diederixi were identified. This was followed by biozonation with the aid of standard zonation scheme and four (4) zones of pollen and spores comprising of P540, P560, P580 and P5620 were identified based on the Last Downhole Occurrence (Base) and First Downhole Occurrence (Top) of some marker species.

Based on the palynozones identified, the age of the sections penetrated by the well ranges from late Oligocene to early Oligocene, which falls within the Rupelian and Chattian stage while the paleoenvironmental studies of the abundance and diversity of pollens and spores with respect to their environment, shows that most of the species falls within the Brackish water and the Freshwater swamps environments.

Keywords: Palynomorphs; Biozonation; Species; Oligocene; Palynozones

\section{Introduction}

"Pollen and spores" also known as sporomorphs are produced by plants. Lower plants such as ferns produce spores while higher or flowering plants -angiosperms and gymnosperms, produce pollen grains.
Sporomorphs are generally small with sizes ranging from 10 to 20 microns. Shape and ornamentation of the grains vary greatly and allow for their morphological classification. 


\section{International Journal of Paleobiology \& Paleontology}

Previous studies on Pollen and Spores was carried out by Ajaegwu, et al. (2012) [1], Bankole, et al. (2006) [2], Oboh-Ikuenobe, et al. (1999) [3], Oloto (1989) [4], Biffi, et al. (1983) [5], Ravn (1981) [6], Romans (1975), May, et al. (1973) [7], Agasie (1969) [8], Simmons, et al. (1966) [9], Hedlund (1966) [10] and Brenner (1963) [11], where they used it to infer the age of sedimentary deposits and its paleoenvironment.

Though palynological works have been carried out in the Niger Delta basin, but there is little published information due to confidentiality maintained by oil companies within the basin.

Thus, the present study was undertaken to determine the lithostratigraphy of the formation, age and environment of deposition of an oil exploratory well drilled in the Niger Delta through the use of diagnostic palynomorphs.

\section{Geologic Setting of the Area}

The Niger Delta Basin is situated in the Gulf of Guinea in equatorial West Africa, between latitudes $4^{0} \mathrm{~N}$ and $6^{\circ} \mathrm{N}$ and longitudes $5^{\circ} \mathrm{E}$ and $8^{\circ} \mathrm{E}$ as shown in Figure 1. The Niger Delta is framed on the northwest by a subsurface continuation of the West African Shield, the Benin Flank. The eastern edge of the basin coincides with the Calabar Flank to the south of the Oban Masif [12] as shown in Figure 1.



Figure 1: Geologic map of the Niger Delta region (after Correldor, et al. 2005) [13]. 


\section{International Journal of Paleobiology \& Paleontology}

Well sections through the Niger Delta generally display three vertical lithostratigraphic subdivisions: an upper delta top facies; a middle delta front lithofacies; and a lower pro-delta lithofacies [14]. These lithostratigraphic units are shown in Figure 2 and correspond respectively with the Benin Formation (Oligocene-Recent), Agbada Formation (Eocene-Recent) and Akata Formation (Paleocene-Recent) of Short, et al. (1967) [15]. The Akata Formation is composed mainly of marine shales, with sandy and silty beds which are thought to have been laid down as turbidites and continental slope channel fills. It is estimated that the formation is up to 7,000 metres thick [16]. The Agbada Formation is the major petroleumbearing unit in the Niger Delta. The formation consists mostly of shoreface and channel sands with minor shales in the upper part, and alternation of sands and shales in equal proportion in the lower part. The thickness of the formation is over 3,700 metres. The Benin Formation is about 280 metres thick, but may be up to 2,100 metres in the region of maximum subsidence [17], and consists of continental sands and gravels.
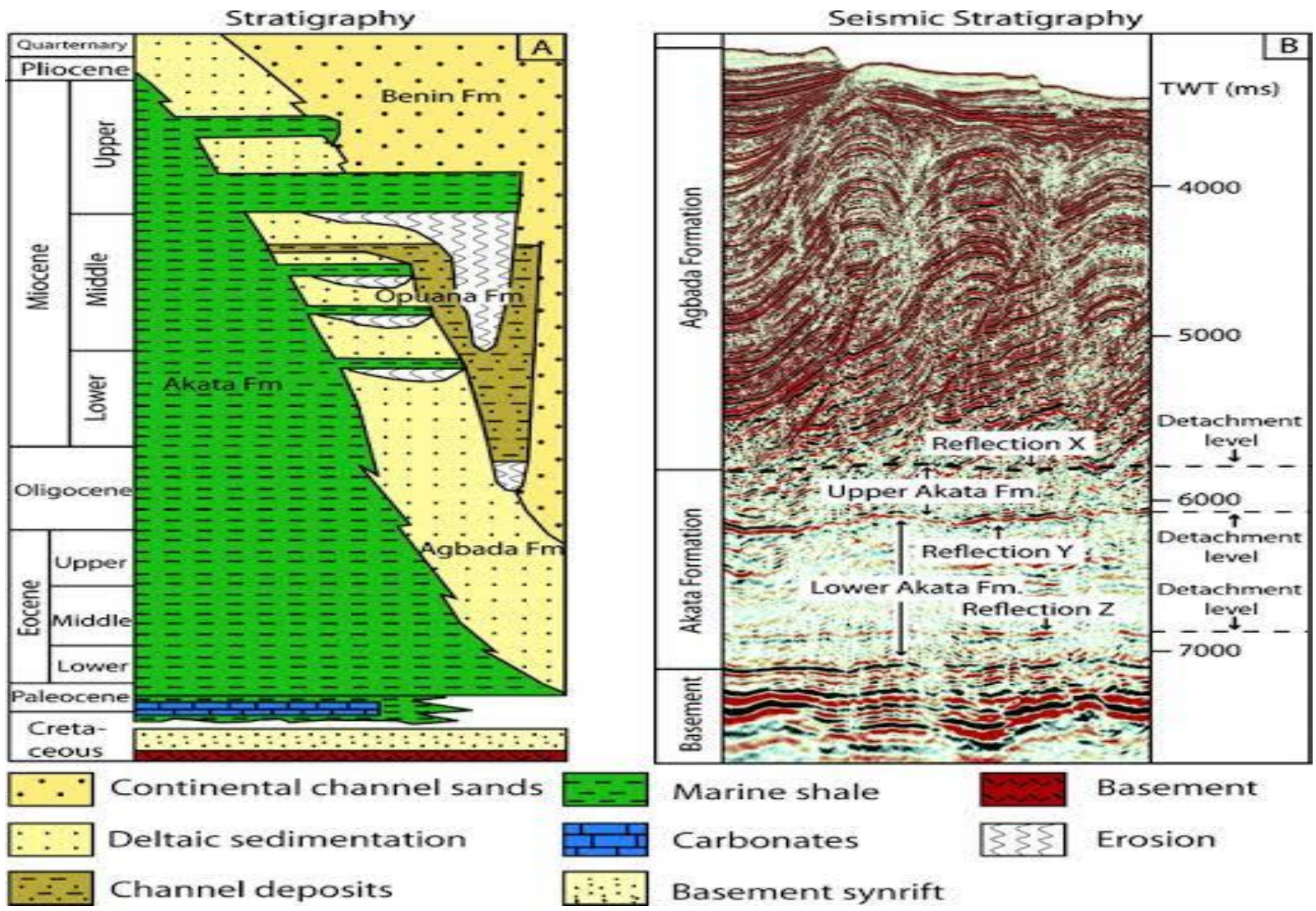

Figure 2: Stratigraphic Section of Niger Delta [16].

The section studied falls within the Biafra Member of the Agbada Formation of the Niger Delta basin as classified by Opara, 1981 [18].

\section{Materials and Methods}

In carrying out palynomorphs' analysis using ditch cutting samples, the following tools were put into use for extraction of pollen and spores: ditch cuttings, centrifuge machine, fume cupboard, brason sonifier 250, well labelled plastic cups, hot plate, beakers, test tubes, warmer, distilled water, glass slides/bottle cover slips, pipette, sample bags, water distiller, loctite impruv (adhesive), hand gloves and optical microscope.

Ditch cutting samples were used and they were composited at $60 \mathrm{ft}$ intervals. A total of 60 samples from depth of $6100 \mathrm{ft}$ to $11690 \mathrm{ft}$ were processed and analyzed 


\section{International Journal of Paleobiology \& Paleontology}

for sedimentological and palynological characteristics. The sedimentological characterization was done by visual inspection of the colour, grain size and textural composition of the various lithologies penetrated by the well.

Palynomorphs processing involves the use of 30 grams of each samples which was crushed to size between $0.25 \mathrm{~mm}$ and $2.5 \mathrm{~mm}$. This is followed by the addition of concentrated hydrofluoric acid (HF) to remove the silicate materials. This process is called "soaking" and was done overnight (15hours) in a fume cupboard after which water was added, stirred and allowed to settle before it was decanted leaving behind the residue.

Hydrochloric acid ( $\mathrm{HCl})$ was later added to the sample to remove the calcareous material. This was followed by the addition of $\mathrm{H}_{2} \mathrm{O}$ (distilled water) and decanting.

Nitric acid was then added to help concentrate the palynomorphs by burning off cellulose so that the slide will be clearer. $\mathrm{ZnBr}_{2} / \mathrm{ZnCl}_{2}$ was used for density separation. That is to separate the palynomorphs from larger fragments. This allows the floating and easy collection of the palynomorphs which was then carefully collected into a test tube.

The palynomorphs were then mounted using the mounting medium to produce the slides and one slide per sample was analyzed under the optical microscope and the microphotography of the best palynomorphs specimen was done with the aid of an "Olympus CBH" microscope.

The specimen (palynomorphs) morphological characteristics were then compared with the descriptions, monographs and diagrams of available publications which include publications of Gonzalex (1967) [19], Germeraad, et al. (1968) [20], Legoux (1978) [21], Adegoke, et al. (1978) [22], Salami (1983) [23] and Sowunmi (1995,1999) $[24,25]$ and the palynozones were described using the zonation scheme of Germeraad, et al. 1968 [20] and Evamy, et al. 1978 [26]. While the palynological and lithological chart of the Well were displayed with the aid of the Strata Bug Graphical software.

\section{Results and Interpretation}

\section{Lithologic Description}

A lithostratigraphic unit is defined as a body of rock which is distinguished and delineated on the basis of lithic characteristics and stratigraphic position. This unit generally conforms to the Law of Superposition and is commonly stratified and tabular in form.

The SEG-1 well is lithologically characterized by a coarsening upward sequence from a sequence of intercalation of sandy mudstone and argillaceous sandstone, to mixed sandstone (70\% coarse) and at the top sandstone (coarse) (as shown in Table 1, Figures 3 \& 4). The intercalation of sandy mudstone, argillaceous sandstone, to mixed sandstone and coarse sandstone reveals that SEG-1 well penetrates the Agbada Formation of the Niger Delta basin. This is because of its similarities to the Agbada Formation which is made up of shoreface and channel sands with minor shales in the upper part, and alternation of sands and shales in equal proportion in the lower part.

\begin{tabular}{|c|c|}
\hline DEPTH (ft) & LITHOLOGY \\
\hline $6110-6620$ & Sandstone \\
\hline $6640-6800$ & Argillaceous sandstone \\
\hline $6800-6975$ & Mixed sandstone \\
\hline $6975-7175$ & Argillaceous sandstone \\
\hline $7175-7200$ & Sandy mudstone \\
\hline $7200-7850$ & Argillaceous sandstone \\
\hline $7850-8250$ & Intercalation of argillaceous sandstone \\
& and mudstone \\
\hline $8250-8510$ & Argillaceous sandstone \\
\hline $8510-8925$ & Intercalation of argillaceous sandstone \\
& and mudstone \\
\hline $8925-9025$ & Argillaceous sandstone \\
\hline $9025-9750$ & Intercalation of argillaceous sandstone \\
& and mudstone \\
\hline $9750-10100$ & Sandy mudstone \\
\hline $10100-10175$ & Argillaceous sandstone \\
\hline $10175-10200$ & Sandy mudstone \\
\hline $10200-10250$ & Argillaceous sandstone \\
\hline $10250-10630$ & Sandy mudstone \\
\hline $10630-10650$ & Argillaceous sandstone \\
\hline $10650-11040$ & Sandy mudstone \\
\hline $11040-11135$ & Argillaceous sandstone \\
\hline $11135-11250$ & Sandy mudstone \\
\hline $11250-11315$ & Argillaceous sandstone \\
\hline $11315-11500$ & Sandy mudstone \\
\hline $11500-11650$ & \begin{tabular}{c} 
Argillaceous sandstone \\
\hline $11650-11690$
\end{tabular} \\
\hline
\end{tabular}

Table 1: Lithostratigraphic characteristics of SEG-1 Well. 


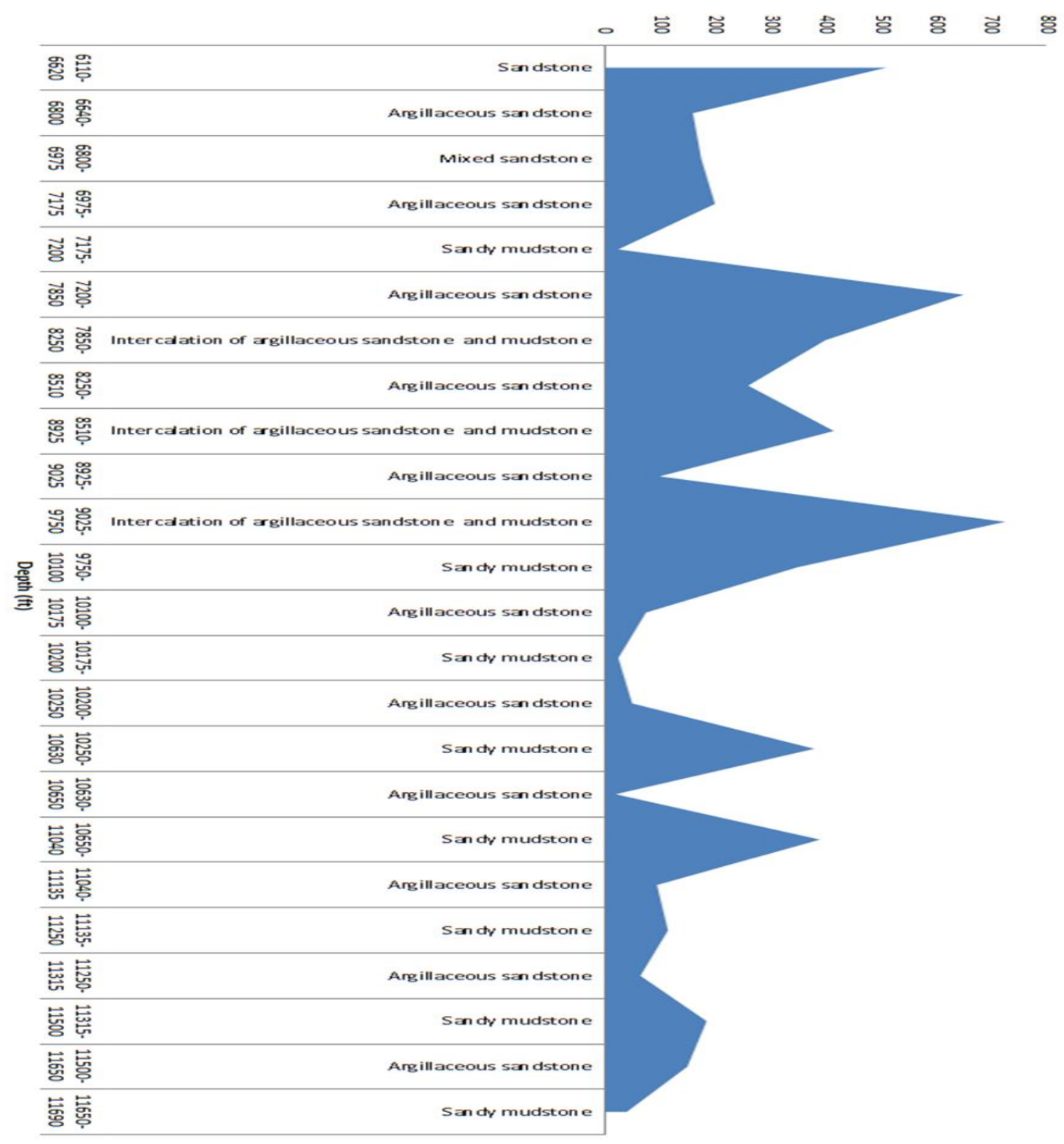

Figure 3: Lithostratigraphic characteristics of the SEG-1 Well. 


\section{International Journal of Paleobiology \& Paleontology}

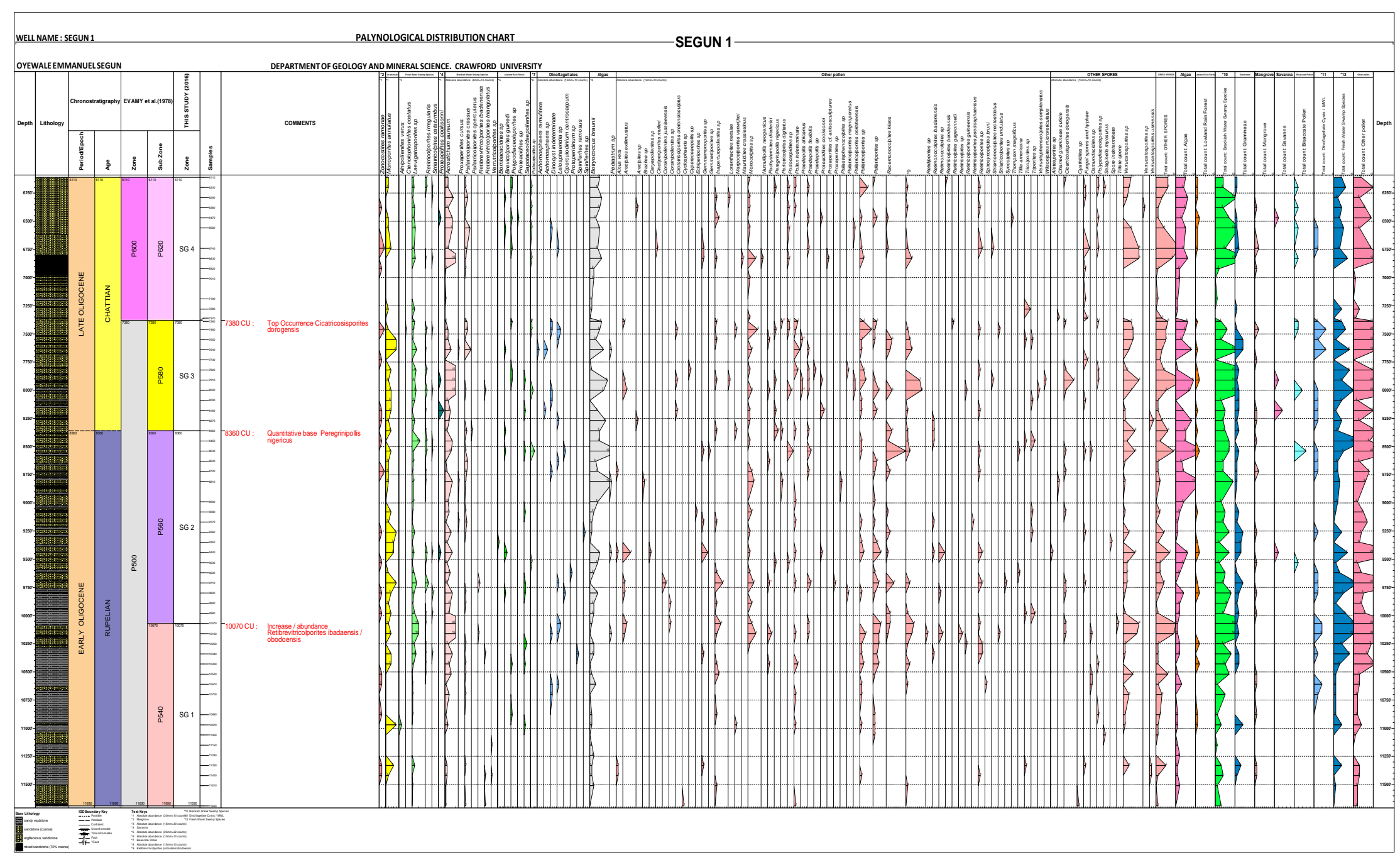

Figure 4: Chart showing the distribution, abundance and the paleoenvironment of the palynomorphs. 


\section{International Journal of Paleobiology \& Paleontology}

\section{Palynostratigraphy}

A total of one hundred (100) species of pollen and spores were identified in SEG-1 well as shown in Figure 4. This comprises of spores, pollen, dinoflagellates and algae while 12 marker species comprising of Retibrevitricolporites obodoensis/ibadanensis, Peregrinipollis nigericus, Cicatricosisporites dorogensis, Sapotaceoidaepollenite sp, Pachydermites diederixii, Zonocostites ramonae, Acrostichum aureum, Botryoococcus braunii, Polypodiacoisporite $s p$ and Monocoporites annulatus amongst others as shown in Figures 4 \& 5 were identified.
Based on the distribution, diversity and abundance of the pollen and spores identified in the studied well, various deductions were made from the chart generated by the Stratabug software. These include the palynozones by Evamy, et al. [26] and Germeraad, et al. 1968 [20], age of the lithologies penetrated by the well and the environment of deposition of the sediments as well as the pollen and spores species identified.

Using the zonation scheme of Evamy, et al. 1978 [26], two (2) palynozones were recognized in the well based on the first and last downhole occurrence of the marker species. These are P500 with subzones P540, P560, P580 and P600 with subzone P620 as shown in Figures 4-6.

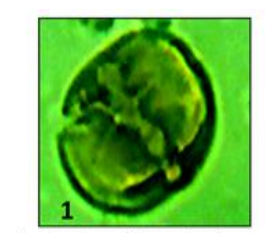

1. Sapotaceoidaepollenites sp.

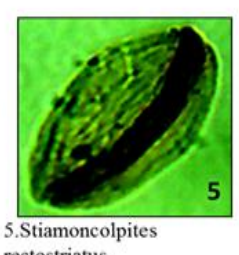

rectostriatus

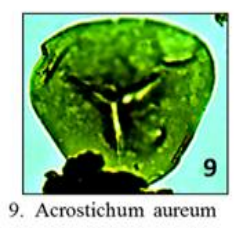

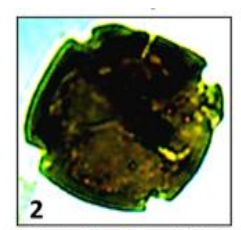

2. Pachydermites diederixi
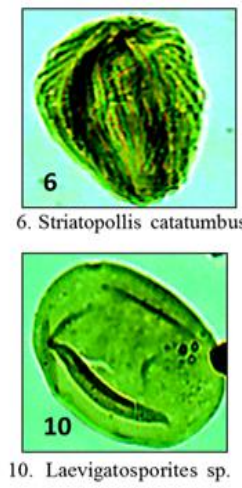

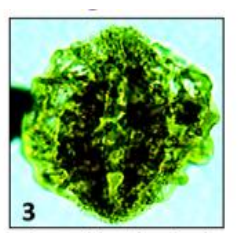

3. Peregrinipollis nigericus
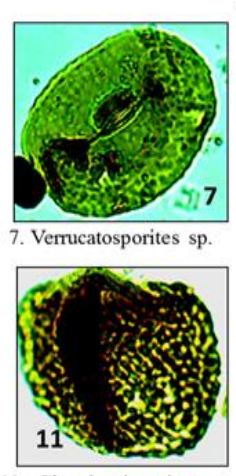

11. Cicatricosisporites dorogensis

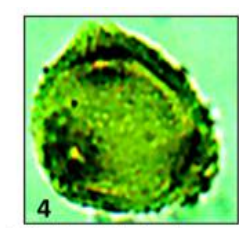

4. Retibrevitricolporites obodoensis/protruden
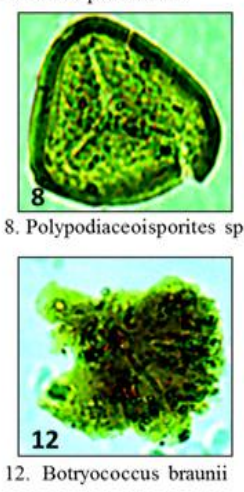

Fig. 5: Identified marker species comprising of pollen and spores in SEG-1 Well (x400)

1. Sapotaceoidaepollenites sp (Protonie et al.); 2. Pachydermites diederixi (Germeraad, et al.) [20]; 3. Peregrinipollis nigericus (Clark); 4. Retibrevitricolporites obodoensis/protrudens (Van Hoeken-Klinkenberg); 5. Stiamoncocolpites rectotriatus; 6. Striatopolls catatumbus (Gonzalez-Gruzman); 7. Verrucatosporites sp (Pflug and Thomas); 8. Polypodiaceoisporites sp(Potonie); 9. Acrostichum aureum (P.H. Frietel); 10. Laevigatosporites sp (Ibrahim); 11. Cicatricosisporites dorogensis (Potonie and Gelletich); 12. Botryococcus braunii (Kutzing).

\section{Palynozones of the Pollen and Spores}

The palynozones established is based on the work of Evamy, et al. 1978 [26] and Germeraad, et al. 1968 [20] as shown in Figure 5. These include the following:

Zone: P620

Age: Late Oligocene (Chattian).

Interval: $6020 \mathrm{ft}-7380 \mathrm{ft}$.

Discussion: The upper part of this interval coincides with the first set of samples analyzed. The base of the interval is marked by the first downhole occurrence of Cicatricosisporites dorogensis at $7380 \mathrm{ft}$. This zone is related to the P620 palynological zone of Evamy, et al. (1978) [26] and lies within the Magnastriatites Howardi palynozones of Germeraad, et al. (1968) [20]. Other palynomorphs characterizing these zones include Monocoporites annulatus, Zonocostites ramonae and Striastriocolpites catatumbus.

Zone: P580. 


\section{International Journal of Paleobiology \& Paleontology}

Age: Late Oligocene (Chattian).

Interval: $7380 \mathrm{ft}-8360 \mathrm{ft}$.

Discussion: The top of this zone was marked by the cicatricosisporites dorogensis at $7380 \mathrm{ft}$. The base is marked by occurrence of peregrinipollis nigericus at $8360 \mathrm{ft}$. This zone is related to the P580 palynological zone of Evamy, et al. (1978) [26] and the Magnastriatites Howardi Zone of Germeraad, et al. 1968 [20]. Other palynormorps characterizing this zone include Acrostichum aureum, Proxapertites cursu Monoporites annulatus and Retibrevitricolporites triangulatus.

Zone: P560.

Age: Early Oligocene (Rupelian).

Interval: $8360 \mathrm{ft}-10070 \mathrm{ft}$.

Discussion: The top of this zone was marked by the Peregrinipollis nigericus at $8360 \mathrm{ft}$. The base is marked by the occurrence of Retibrevitricolporites ibadaensis/obodoensis at $10070 \mathrm{ft}$. This zone is correlated to the P560 palynological zone of Evamy, et al. (1978) [26] and the Magnastriatites Howardi Zone of Germeraad, et al. 1968 [20]. The other pollen and spores abundant at this zone include Acroticum aureum, Monoporites annulatus, Cicatricosisporites dorogenesis and Retiricolporites irregularis.

Zone: P540.

Age: Early Oligocene (Rupelian).

Interval: $10070 \mathrm{ft}-11690 \mathrm{ft}$.

Discussion: The top of this zone was marked by the Retibrevitricolporites ibadaensis/obodoensis at $10070 \mathrm{ft}$. the base of this zone coincides with the last sample analyzed at $11690 \mathrm{ft}$ of the early Oligocene (Rupelian) age. The zone is correlated to the P540 of the palynological zone of Evamy, et al. (1978) [26] and the Magnastriatites Howardi Zone of Germeraad, et al. (1968) [20]. Other abundant species in this zone are Botryoccocus braunii and Spirosyncolpite bruni.

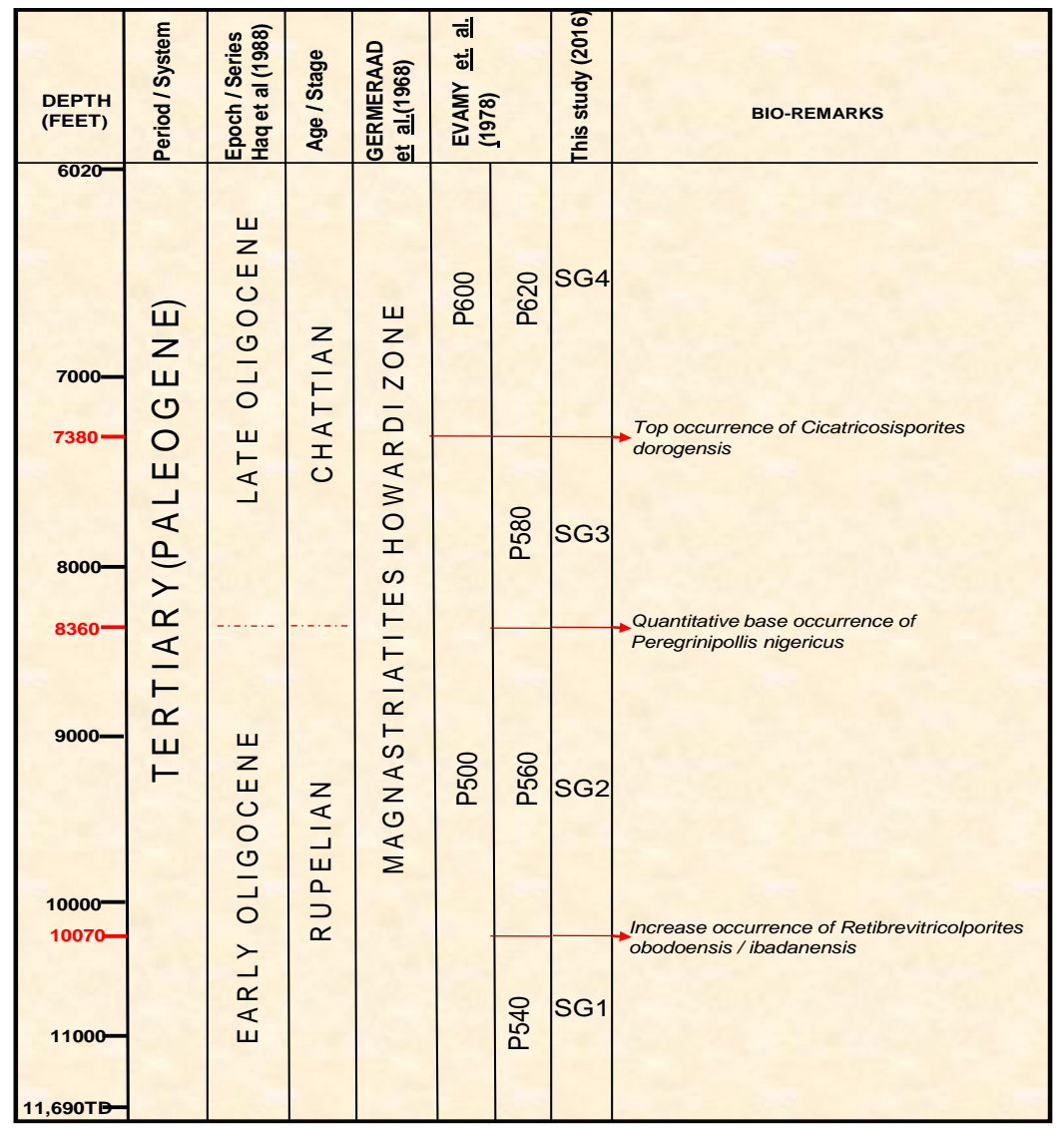

Figure 6: Comparism of Palynozones in SEG-1 Well $(6020 \mathrm{ft}-11,690 \mathrm{ft})$ with other workers. 


\section{International Journal of Paleobiology \& Paleontology}

\section{Stratigraphic Age of the Palynomorphs Identified}

SEG-1 well is an exploratory well drilled in the offshore Western Niger Delta. The age of the formations penetrated by the well is in the Paleogene and the sections penetrated by the well ranges from early Oligocene to late Oligocene in the Chattian, et al. [26], which divides the P-Zones to P540, P560, P580 and P620 zones as shown in Figure 5 above.

\section{Paleoenvironment of the Well}

The depositional environment of the well was interpreted based on the sedimentological characteristics and the palynomorphs identified in the section penetrated by the well.

The vegetation of the studied area mostly depends on ecological conditions, thus any palynomorphs association is characteristic of a specific environment. The distribution of the species identified with respect to their environment is shown in Tables $2 \& 3$ below.

\begin{tabular}{|c|c|c|}
\hline Species & Age Range & Environment \\
\hline Botryococcus braunii & 295.0 to $11.608 \mathrm{Ma}$ & Fluvial, Mire/Swamp, Coastal \\
\hline Cicatricosisporites dorogensis & 125.45 to $40.4 \mathrm{Ma}$ & Fluvial-Deltaic \\
\hline Laevigatosporites $s p$ & 391.9 to $0.126 \mathrm{Ma}$ & $\begin{array}{c}\text { Marine, Lacustrine, Fluvial-deltaic,Coastal, } \\
\text { Mire/Swamp Lagoonal, Fluvial-Lacustrine }\end{array}$ \\
\hline Acrostichum aureum & 55.8 to $0.0 \mathrm{Ma}$ & Fluvial, Marginal Marine, Terrestrial \\
\hline Polypodiaceoisporites $s p$ & 125.45 to $5.332 \mathrm{Ma}$ & Fluvial-Deltaic, Mire/Swamp, Terrestrial \\
\hline Verrucatosporites $s p$ & 112.6 to $11.608 \mathrm{Ma}$ & Deltaic, Lagoonal, Lacustrine, Marine, Coastal \\
\hline Striatopollis catatumbus & 48.6 to $37.2 \mathrm{Ma}$ & Fluvial-Deltaic, Terrestrial \\
\hline Retibrevitricolpites obodoensis/protrudens & 55.8 to $37.2 \mathrm{Ma}$ & Fluvial-Deltaic, Lagoonal \\
\hline Sapotaceoidaepollenites $s p$ & 84.9 to $11.608 \mathrm{Ma}$ & Terrestrial, Coastal, Alluvial Fan \\
\hline
\end{tabular}

Table 2: Environment of deposition of marker species identified in SEG-1 Well.

\begin{tabular}{|c|c|c|}
\hline S/N & Environment & Total Counts of Species \\
\hline 1 & Lowland Rain Forest & 29 \\
2 & $\begin{array}{c}\text { Brackish Water Swamp } \\
\text { specie }\end{array}$ & 298 \\
\hline 3 & Mangrove & 21 \\
\hline 4 & Savanna & 5 \\
\hline 5 & Freshwater Swamp & 207 \\
\hline
\end{tabular}

Table 3: Distribution of Pollen and Spores identified in SEG-1 well and their corresponding environment.

\section{Savanna Group}

In this environment, a total number of five (5) species were identified. The rare existence of pollen and spores in this environment indicates that Savanna is not the major environment in the studied section, but the least as regard the abundance of the pollen and spores present in the section. An example of pollen identified is the Monoporites annulatus which is suggestive of vegetation found in the savanna.

\section{Mangrove Group}

The total count of species in this environment is twenty one (21), indicating that it is not the major environment in the studied well. An example identified in the well is Zonocostites ramonae which is a pollen found in the mangrove that botanically belongs to the Rhizophoraceae [20,27].

\section{Low land Rain Forest Group}

In this environment, a total count of twenty nine (29) species was identified, which implies that it is not a prevailing environment in the section. Examples of these species include Polypodiaceoisporites sp, Bombacacidites $s p$ and Pachydermites diederixii which are an angiosperm of plant from dense rain forest.

\section{Fresh Water Swamp Group}

The freshwater swamp is the second most dominant environment in the studied area as two hundred and seven (207) total counts species were identified in the drilled exploratory well. Examples of these species include Alnipollenites verus, Laevigatosporites $s p$ and Striatricolpites catumbus.

\section{Brackish Water Swamp Group}

The brackish water swamp environment has the highest total counts of species, of which two hundred and 


\section{International Journal of Paleobiology \& Paleontology}

ninety eight (298) pollen and spores were identified. This implies that this environment supported the growth and reproduction of pollen and spores, with favourable conditions in their life span. Examples of these species include Acrostichum aureum which are principal climbing fern adapted to coastal areas. That is areas inundated with saline water, open salt marshes, coastal swamps and estuaries [28-30].

\section{Conclusion}

Sixty (60) ditch cutting samples retrieved from the SEG-1 Well drilled in the shallow offshore of Niger Delta, from $6110 \mathrm{ft}$ to $11690 \mathrm{ft}$ at $60 \mathrm{ft}$ intervals were employed for palynostratigraphic study of the well. The total number of pollen and spores identified were one hundred (100) species.

Based on the distribution and occurrence of marker species, four palynozones were established: P540 (Retibrevitricolporites obodoensis/ibadanensis), P560 (Peregrinipollis nigericus), P580 (Cicatricosisporites dorogensis) and P620 (Monocoporites annulatus). In the paleoenvironment distribution of the species identified, the highest diversity is found in the brackish water swamp while the least exists in the savanna.

Thus, the zones have been assigned an early Oligocene to late Oligocene [31] with a corresponding Rupelian and Chattian stage according to the work of Evamy et al., 1978, and stratigraphic age ranging from 33.9Ma to 23Ma.

Also, the paleoenvironmental studies based on the abundance of the pollens and spores with respect to their paleoenvironment revealed that most of these species falls within the brackish water and the freshwater swamps.

\section{References}

1. Ajaegwu NE, Odoh BI, Akpunomu EO, Obiadi II, Anakwuba EK (2012) Late Miocene to Early Pliocene Palynostratigraphy and Paleoenvironments of ANE1 well, Eastern Niger Delta. Nigeria. Journal of Mining and Geology 48(1): 31-43.

2. Bankole SI, Shrank E, Erdtmann BD, Akande SO (2006) Palynostratigraphic Age and Paleoenvironments of the newly exposed section of the Oshosun Formation in the Sagamu quarry, Dahomey Basin, Southwestern, Nigeria. Nigerian Association of Petroluem Explorationists Bulletin 19(1): 25-34.
3. Oboh-Ikuenobe FE, Hoffmeister AP, Chrisfield RA (1999) Cyclic Distribution of dispersed organic matter and dinocysts, ODP site 959 (Early Oligocene Early Miocene, Côte d'Ivoire - Ghana Transform Margin). Palynology 23(1): 87-96.

4. Oloto IN (1989) Maastrichtian dinoflagellate cyst assemblage from the Nkporo Shale on the Benin flank of the Niger Delta. Review of Palaeobotany and Palynology 57(3-4): 173-186.

5. Biffi U, Grignani D (1983) Peridinioid dinoflagellate cysts from the Oligocene of the Niger Delta, Nigeria. Micropaleontology 29(2): 126-145.

6. Ravn RL (1981) Preliminary observations on the palynology of upper Dakota lignites from northwestern Iowa and northeastern Nebraska. In: Brenner RL, et al. (Eds), Cretaceous stratigraphy and sedimentation in northwest Iowa, northeast Nebraska, and southeast South Dakota. North-Central Section, Geological Society of America, Iowa Geological Survey Guidebook Series. 4: 123-127.

7. May FE, Traverse A (1973) Palynology of the Dakota sandstone (middle cretaceous) near Bryce canyon national park, Southern Utah. Geoscience and Man 7(1): 57-64.

8. Agasie JM (1969) Late Cretaceous palynomorphs from northeastern Arizona. Micropaleontology 15(1): 13-30.

9. Simmons MD, Bidgood MD, Brenac P, Crevello PD, Lambiase JJ, et al. (1966) The Paleocene pollen flora of Colombia: Leidse Geologische Mededelingen 35: 105-116.

10. Hedlund RW (1966) Palynology of the Red Branch Member of the Woodbine Formation (Cenomanian), Bryan County, Oklahoma. The University of Oklahoma, Norman.

11. Brenner GJ (1963) The spores and pollen of the Potomac Group of Maryland, pp: 215.

12. Murat RC (1972) Stratigraphy and Palaeogeography of the Cretaceous and Lower Tertiary in Southern Nigeria, in African Geology, In: Dessauvagie TFJ, et al. (Eds), Ibadan University Press, pp: 251- 266.

13. Correldor F, Shaw JW, Bilotti F (2005) Structural styles in the deeper-water fold and thrust belt of the 


\section{International Journal of Paleobiology \& Paleontology}

Niger Delta. American Association of Petroleum Geologists Bulletin 89(6): 753-770.

14. Reijers TJA, Petters SW, Nwajide CS (1996) The Niger Delta Basin, In: Reijers TJA (ed.), Selected Chapters on Geology. SPDC corporate reprographic services, Warri, Nigeria, pp: 103-114.

15. Short KC, Stauble AJ (1967) Outline of geology of Niger Delta. AAPG Bulletin 51(5): 761-779.

16. Doust H, Omatsola E (1990) Niger Delta. In: Edwards JD, et al. (Eds), Divergent/passive margin basins. American Association of Petroleum Geologists Memoir 48: 201-239.

17. Whiteman A (1982) Nigeria: its petroleum geology, resources and potential. Graham \& Trotman Ltd, 1: 114-131.

18. Opara GE (1981) Areview of the Tertiary Unam B Field in OML67, Niger Delta. Journal of Mining and Geology 18(1): 86-95.

19. Gonzalez Guzman AE (1967) A palynological study of the Upper Los Cuervos and Mirador Formations (Lower and Middle Eocene; Tibu area, Colombia): E J Brill, Leiden, pp: 23-48.

20. Germeraad JH, Hopping CA, Muller J (1968) Palynology of Tertiary sediments from tropical areas. Review of Paloebotany and Palynology 6(3-4): 189348.

21. Legoux O (1978) Quelques especes de pollen caracteristiques du Neogene du Nigeria: Bull.Cent. Rech. Explor.-Prod Elf-Aquitane 2(2): 265-317.

22. Adegoke OS, Chene RE, Jan du, Agumanu AE, Ajayi PO (1978) Palynology and age of Kerri-Kerri Formation, Nigeria. Revista Espanola de Micropaleontologia 10(2): 267-283.
23. Salami MB (1983) Some Late Cretaceous and Early Tertiary Pteridophytic spores from the Southern, Nigeria sedimentary basin. Revista Espanola de Micropaleontologia 15(2): 257-272.

24. Sowunmi MA (1995) Pollen of Nigeria Plants. Scandinavian University Press, 120-141.

25. Sowunmi MA (1999) The significance of oil palm (Elaeis guineensis Jacq.) in the Late Holocene environments of west and west central Africa: A further consideration. Vegetational History and Archaeobotany 8(3): 199-210.

26. Evamy BD, Haremboure J, Karmeling, Rowlands PH (1978) Hydrocarbon habitat of the Tertiary Niger Delta. American Association of Petroleum Geologists Bulletin 62: 277-298.

27. Van der Hammen $\mathrm{T}$ and Wymstra TA (1964) A palynology study on the Tertiary and Upper Cretaceous of British Guiana. Leidse Geologische Mededelingen 30(1): 183-241.

28. Kar RK (1992) Occurrence of Acrosticum spores from the Langpar Formation, Early Palaeocene of Meghalaya, India. Geophytology 22: 33-36.

29. Graham A (1995) Diversification of Gulf/Caribbean mangrove communities through Cenozoic time. Biotropica 27(1): 20-27.

30. Ramcharan EK and McAndrews JH (2006) Holocene development of coastal wetland at Maracas Bay, Trinidad, West Indies. Journal of Coastal Research 22(3): 581-586.

31. Haq BU, Hardenbol J, Vail PR (1987) Geochronology of Flunctuating Sea levels since the Triassic. Science 23: 1156-1166. 